\title{
Indonesia Macro Economy Stability Pattern Prediction (Mundell-Flamming Model)
}

\author{
Rusiadi $^{1}$, Ade Novalina ${ }^{2}$, Prawidya Khairani ${ }^{3}$, Andysah Putera Utama Siahaan ${ }^{4}$ \\ ${ }^{1,2)}$ Faculty ofEconomics and Business, Universitas Pembangunan Panca Budi, Medan, Indonesia \\ ${ }^{3)}$ Faculty ofEconomics and Business, Universitas Muhammadiyah Sumatera Utara, Medan, Indonesia \\ ${ }^{4)}$ Faculty of Computer Science,Universitas Pembangunan Panca Budi, Medan, Indonesia
}

\begin{abstract}
This study examines whether economic stability in Indonesia capable predicted by the model Mundell-Fleming. Prediction proxy stability of the interaction of fiscal and monetary policy. During Indonesia's economic stability is largely determined by the strength of economic fundamentals, while economic fundamentals are strongly influenced by fiscal and monetary policies. Therefore flemming Mundell predicts how strong the economic stability in Indonesia?, the statement in the analysis by using a long-term predictions are Vector Autoregression. Research findings indicate patterns of interaction predictions variety of fiscal and monetary policy, both short term, medium term and long term. It turned out that fiscal policies are derived from taxes are more effective than government spending to control economic growth, investment and inflation, but government spending is more effective to control the exchange rate. The monetary policy of interest rates more effectively control the exchange rate and inflation, while the money supply is more effective in controlling the growth of economy and investment.
\end{abstract}

Keyword:Mundell-Fleming, Macroeconomic Stability, Fiscal Policy, Monetary Policy.

\section{Introduction}

Prediction their economic stability can be seen on the stability of macroeconomic variables on the interaction of fiscal and monetary policy. Fiscal policy and monetary policy is an integral part of macroeconomic policy has a target to be achieved both in the short, medium and long term. Fiscal and monetary policy management through better coordination would give a positive signal for the market and maintain macroeconomic stability. Macroeconomic models are often used to analyze how fiscal and monetary policy in an open economy is the Mundell-Fleming model. This model is described as "domain policy model for studying monetary and fiscal policy in open economies" (Mankiw, 2007). The Mundell-Fleming makes an important and strategic assumptions; this model assumes that the economy being studied is an open economy with perfect mobility, which means that the policies taken by the government fiscal and monetary policies will have an impact on other economic variables that disrupt macroeconomic stability.

The phenomenon is caused by the impact of monetary and fiscal policies often lead to inflation. In 2013 inflation of $8.3 \%$ due to rising fuel prices. The existence of three stages of interaction in which the response of macroeconomic variables to shocks originating from the interaction of fiscal and monetary policy shows the direction of movement in the period 2000 to 2014. In the first stage of interaction that is a range of $2001 \mathrm{~s} / \mathrm{d}$ in 2002, where the rise inflation in 2001 amounted to $12.55 \%$ expected because of the increase in fuel prices and the increase in public spending following religious event holidays between adjacent Eid, Christmas and new year, thus increasing demand, basic materials. The increase in inflation followed by a decline in GDP growth in 2001 from the previous year growth or slower economic growth and the impact on money supply growth slows in 2002 which resulted from the monetary response to inflation, and the decline in government spending in 2002.

In the second stage of interaction that is a range of $2005 \mathrm{~s} / \mathrm{d}$ in 2006, where the rise in inflation in 2005 amounted to $17.11 \%$ expected because of the expansion of the fiscal year 2005, which the government increased expenditure by $32.25 \%$ which is dominated by the increase in recurrent expenditure such as salaries rise, causing inflation, and the impact the decline in GDP growth in 2006 from the previous year's growth or slowing economic growth. In the third stage of interaction that is a range of $2008 \mathrm{~s} / \mathrm{d}$ in 2009 , where the rise in inflation in 2008 amounted to $11.06 \%$ expected because of the global economic crisis. The increase in inflation was accompanied by the decline in the growth of money supply growth in 2008 than the previous year due to the monetary response to inflation, and the impact the decline in government spending in 2009 and the decline in GDP growth in 2009 from the previous year's growth or slowing economic growth.

According to Mohanty and Scatigna (2010) policy is done partially and gradually tends to be further increased uncertainties and risks, which may encourage further economic slowdown. To that end, many economists suggest strategies that should be taken is policy coordination and use of various policy instruments more aggressively to support the effectiveness of the measures taken. Adiningsih (2012) states that the 
coordination of monetary and fiscal policies have become more important when there is a high uncertainty of the effect of each policy. Corsetti and Mueller (2008) which states that fiscal policy will be more efficient when coupled with an accommodative monetary policy. In other words, so that fiscal stimulus can run well, monetary policy should be directed to boost economic growth, which is consistent with the mandate of maintaining price stability.

The study specifically predicts when stability will be achieved has not been done, even for special uses, Mundel approaches Fleming with Autoregression Vector tool capable of predicting the short-term, medium-term and to long term, not in Indonesia. Formulation of the problem in this research is: "Is the Mundell-Fleming model can form a pattern predictive macroeconomic stability? The purpose of this study is: "Finding patterns for prediction of macroeconomic stability by analyzing the Mundell-Fleming model. The hypothesis in this study are: Study of the Mundell-Fleming model can form a pattern predictive macroeconomic stability in Indonesia.

\section{Theories}

\section{Money market equilibrium and Goods Market (IS * - LM *), Concept Mundell-Fleming As Macroeconomic Stability Prediction Model}

Macroeconomic models are often used to analyze how fiscal and monetary policy in an open economy is the Mundell-Fleming model, which is the final name of the inventor of the model namely, Robert Mundell (1961) and John Fleming (1962). This model is described as "domain policy model for studying monetary and fiscal policy in open economies" (Mankiw, 2007). When running the monetary and fiscal policy, policymakers often observe what is happening in foreign countries. Although domestic prosperity is the sole objective, they need to consider the development of every country. International flows of goods and services, as well as international capital flows, can affect the economy in many ways. The decision-makers who ignore this influence will face the danger (Mankiw, 2007). Mundell-Fleming model is the IS-LM model for a small open economy.

The Mundell-Fleming makes an important assumptions and extreme: This model assumes that the economy being studied is a small open economy with perfect mobility. The definition of a small open economy is an economy that is a small part of the world economy, and by itself does not have a significant impact on the world interest rate. With perfect mobility, means that the population of a country can have full access to the world financial markets. Because of the assumption of perfect capital mobility, the interest rate in a small open perekonomaian (r), must equal the world interest rate (world interest rate). That is, the economy can borrow or lend as much as it wants in world financial markets, and as a result the economy's interest rate is determined by the world relationship $(\mathrm{r}=\mathrm{r} *$ ) (Mankiw, 2007)

Goods Market and the IS * curve on the model of the Mundell-Flaming describes the market for goods and services as the IS-LM model, but this model adds a new symbol for net exports, so the IS * curve is a curve showing the relationship of all income levels and exchange rates laid markets goods and services in a state of balance that revenue is equal to the demand for goods and services. The higher the rate, the lower the income level, with the assumption of perfect capital mobility, so $r=r *$, obtained by the following equation:

$\mathrm{Y}=\mathrm{C}+\mathrm{I}+\mathrm{G}+\mathrm{NX}$

In Mankiw (2006) is an equation indensitas equation, ie an equation that is certainly true views of how the variables - variables that equation elaborated. To more clearly seen: Consumption (consumption) are expenditures for goods and services by households. Dispodible consumption depends positively on income, which has the function: $\mathrm{C}=f(\mathrm{Y}-\mathrm{T})$

Investment is the purchase of goods that will be used to produce more goods and services. Investment is the sum of the purchase of capital equipment, supplies and buildings. Tingka investment is negatively related to the interest, which has a function:

$\mathrm{I}=f(\mathrm{r})$

Expenses / Expenditures are expenditures for goods and services by local governments, the central government which includes wage jobs and spending in the public interest, represented by G. Net exports (net exports) is the purchase of products in the country by foreigners (exports) minus the purchase of foreign products land by nationals (imports). Net exports minus imports refers to the value of exports. Net exports is negatively related to the exchange rate, which has a function:

$\mathrm{NX}=f(\mathrm{e})$

so the result of the substitution C, I, G and NX on IS model is obtained *: 
IS *: Y $=\mathrm{C}(\mathrm{Y}-\mathrm{T})+\mathrm{I}(\mathrm{r})+\mathrm{G}+\mathrm{NX}(\mathrm{e})$

This equation states that the income is the sum of consumption, investment, government spending and net exports, where the consumption of berhantung positively on disposable income, investment is negatively related to the interest rate and net exports negatively related to the exchange rate. This equation is an IS *, which represents the balance of income and the rate on goods and services markets, (asterisk / asterisk indicates that this equation using the assumption of a constant interest rate on the world interest rate $r *$ ).

Money Market and the LM * curve in the Mundell-Flaming models to explain the financial markets as a model IS-LM. LM * curve is a curve showing the relationship between the level of income in the range of possible interest rates putting the money in a state of balance is the money demand equals money supply, by the following equation:

$\mathrm{M} / \mathrm{P}=\mathrm{L}(\mathrm{r}, \mathrm{Y})$

This equation states that the supply of real money balances, M / P, is equal to the demand, L (r, Y). Demand for real money balances depends negatively on the interest rate and positively on the income Y. By adding the assumption that the domestic interest rate is equal to the world interest rate, the LM * equation becomes:

$\mathrm{LM} *: \mathrm{M} / \mathrm{P}=\mathrm{L}(\mathrm{r} *, \mathrm{Y})$

This equation shows that the LM * curve vertically because the exchange rate does not enter into the equation $\mathrm{LM} *$. Based on the world interest rate, the LM* equation determines aggregate income, without considering the exchange rate. LM * curve linking the interest rate that follows the world interest rate and income (Mankiw, 2007). From these equations, the interest rate in question is the domestic real interest rates which followed the world interest rate $(\mathrm{r} *)$, where the real interest rate is the nominal interest rate reduction of inflation, and can be described by the equation:

$\mathrm{r} *=(\mathrm{i}-\pi)$

Substitution into the above equation will produce equilibrium model IS * LM * as follows:

IS *: Y $=\mathrm{C}(\mathrm{Y}-\mathrm{T})+\mathrm{I}(\mathrm{i}-\pi)+\mathrm{G}+\mathrm{NX}(\mathrm{e})$

$\mathrm{LM} *: \mathrm{M} / \mathrm{P}=\mathrm{L}((\mathrm{i}-\pi), \mathrm{Y})$

* IS equation describes the equilibrium in the goods market and the LM * equation describes the equilibrium in the money market. The balance of the economy where the curve IS * and LM * curves intersect. The intersection shows the exchange rate and the income level at which the market of goods and money in the balance. With this diagram, we can use the Mundell-Fleming model to show how the aggregate income Y and exchange policy changes both fiscal policy and monetary policy.

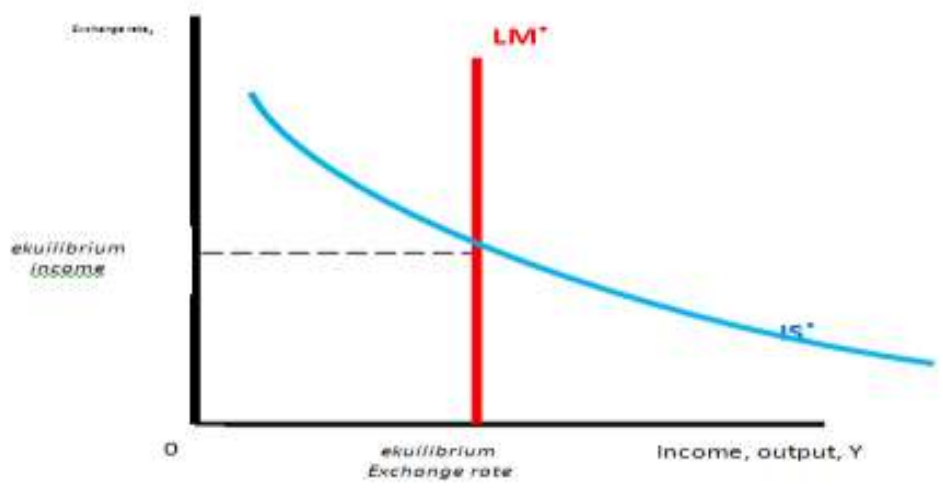

Fig.1IS ${ }^{*}$ and LM* Curvers Balancing (Model Mundell-Fleming)

Based on the Mundell-Fleming model image shows the goods market equilibrium condition IS * and LM * money market equilibrium. Both curves maintain a constant interest rate on the interest rate world. The intersection of these two curves show the level of income and the exchange rate that satisfies equilibrium in both the goods market and in the money market (Mankiw, 2007). 


\section{Methodology}

The parameters measured were the interaction of monetary fiscal against Indonesian macroeconomic stability with an assessment of Mundell-Fleming model, where macroeconomic models are often used to analyze how fiscal and monetary policy in an open economy is the Mundell-Fleming model. These parameters are: fiscal policy on taxes and government spending, monetary policy variables, namely interest rates and the money supply, as well as macroeconomic stability variables that gross domestic product, investment, exchange rates and inflation.Data Analysis Methods in this study is using the Vector method Autoregression (VAR)

\section{Vector Autoregression (VAR)}

This model is able to create a pattern of short-term production, medium and long from the effects of simultaneity between variables, using the formula:

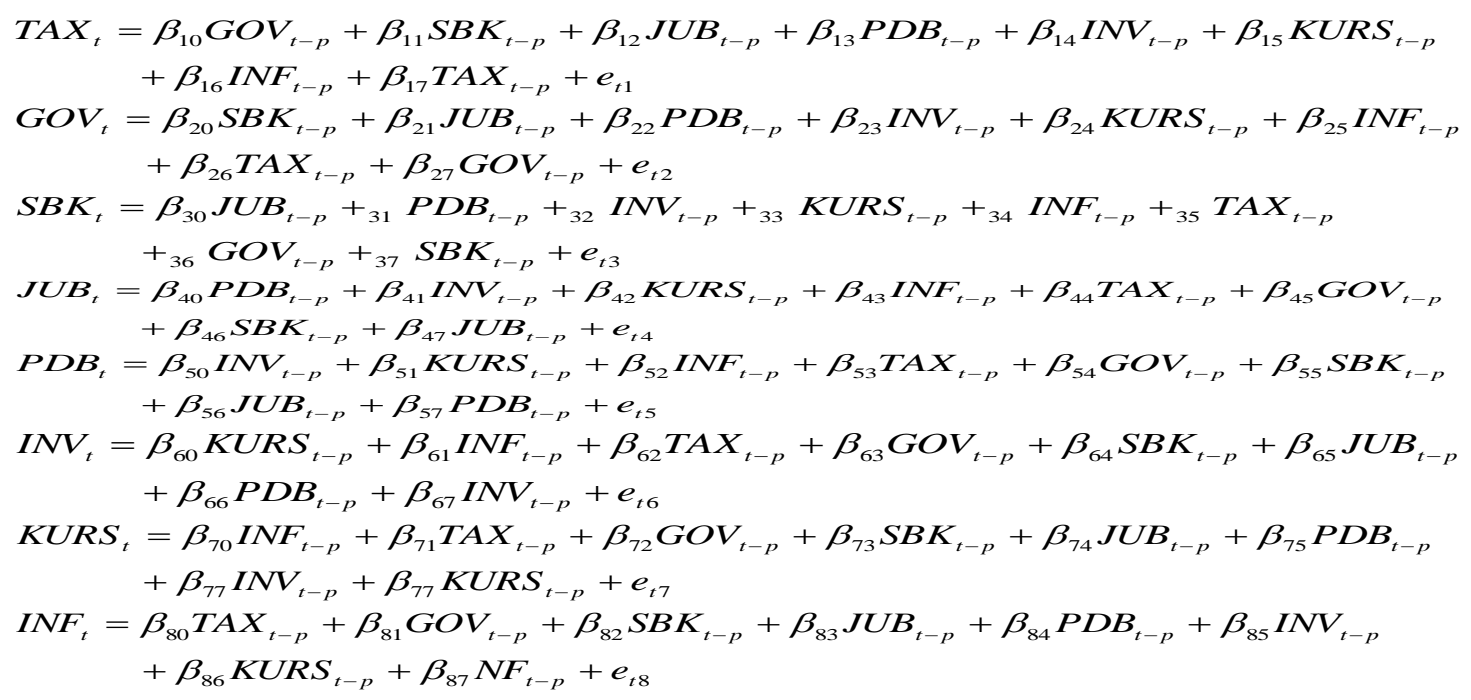

\section{Impulse Response Funtion (IRF)}

Impulse Response Function (IRF) was conducted to determine the dynamic response of each variable to one standard deviation innovation. IRF is a measure of the direction of movement of each variable transmit due to changes in other variables (Manurung, 2009). This model can determine the pattern of prediction of shock or effects between the observed variables.

\section{Forecast Error Variance Decomposition (FEVD)}

Forecast Error Variance Decomposition (FEVD) conducted to determine the relative importance of the various shocks to the variable itself as well as other variables. Identification FEDV using Cholesky decomposition. FEDV analysis aims to determine the effect or contribution between variable transmit (Manurung, 2009). This analysis can form effective policies and make the economy becomes stable.

Test Assumptions:

1. Stationarity test, conducted to see if it contains the root of the time series data unit (unit root). For that, the usual method used is the Dickey-Fuller (DF) and Augmented Dickey-Fuller test (ADF).

2. Test Cointegration, after it emerged that all data will be analyzed stationary, then the next will be tested if there is a relationship long-term balance between all these variables.

3. Structural Stability Test Lag VAR, is done by calculating the roots of polynomial root or roots of the characteristic polynomial. If all the roots of the polynomial function are inside the unit circle or if the absolute value $<1$ then the VAR model is considered to be stable so that the IRF and FEVD considered valid.

\section{Evaluation}

Based on the analysis Forecast Error Variance Decomposition (FEVD) known to some interaction between fiscal policy and monetary policy on macroeconomic stability. The interaction of fiscal and monetary policy variables visible from the Variance Decomposition describes the policy variables more effectively to macroeconomic variables. Here are the results of data analysis and discussion on figure 2 and table 1 . 

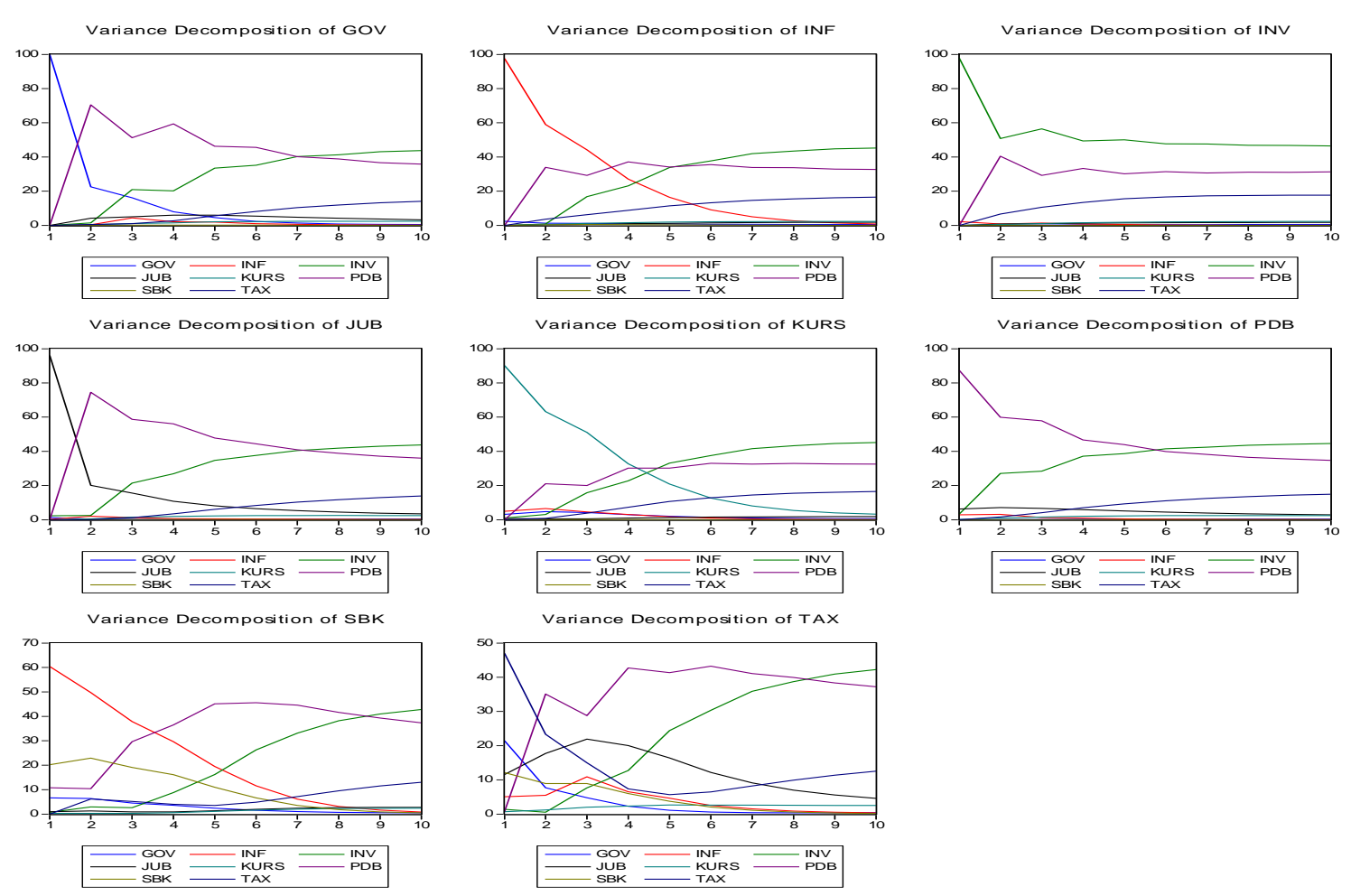

Table 1 Production Patterns of Macroeconomic Stability Mundell-Fleming

\begin{tabular}{|l|l|l|l|l|l|l|l|l|l|l|l|l|l|}
\hline Prediction & \multicolumn{9}{|c|}{ Macroeconomic Stability } \\
\hline & \multicolumn{9}{|l|}{ PDB } & \multicolumn{1}{|l|}{ Imvestation (INV) } & \multicolumn{2}{|l|}{ Exchange Rate (KURS) } & \multicolumn{3}{l|}{ Inflation (INF) } \\
\hline & Short & Midle & Leght & Short & Midle & Leght & Short & Midle & Leght & Short & Midle & Leght \\
\hline TAX & $0,69 \%$ & $15,16 \%$ & $17,40 \%$ & $0,66 \%$ & $4,32 \%$ & $8,07 \%$ & $0,78 \%$ & $2,73 \%$ & $2,73 \%$ & $2,84 \%$ & $3,07 \%$ & $3,25 \%$ \\
\hline GOV & $0,10 \%$ & $6,50 \%$ & $7,26 \%$ & $0,02 \%$ & $4,02 \%$ & $4,99 \%$ & $4,51 \%$ & $11,61 \%$ & $11,61 \%$ & $1,79 \%$ & $2,01 \%$ & $2,08 \%$ \\
\hline
\end{tabular}

Monetary-fiscal prediction pattern towards macroeconomic stability as follows:

\section{Patterns of Interaction Prediction Monetary-Fiscal to GDP}

The interaction of fiscal and monetary most affect GDP, both in the short, medium and long is monetary policy. In the short term, the interaction of fiscal and monetary to GDP is more effectively controlled by the monetary policy through control of interest rates of credit. In the medium and long term fiscal and monetary interaction to GDP is more effectively controlled by monetary policy by controlling the money supply.

It turned out that monetary policy is more effective in the increase in GDP in Indonesia, both in the short, medium and long term. Effectiveness means control policy loan interest rates and the money supply is more effective in increasing output or economic growth compared with the policy of tax revenue and government spending. Monetary policy by lowering loan interest rates will directly encourage increased investment that will increase the GDP, whereas the increase in the money supply will increase people's ability to trade in the short term and invest in the medium and long-term ranges that will drive economic growth.

This study appropriate research Santoso (2009) that the monetary policy impact or a positive impact on the GDP of the fiscal policy. Less influential variables government spending is consistent with the hypothesis Mundell-Fleming, that fiscal policy will lead to crowding expansive Out Effect which confirms the impact of fiscal policy on GDP decline because of rising interest rates. Monetary policy was more effective in increasing the GDP. Adefeso and Mobolaji (2010), in a study of the Nigerian economy during the period 1997-2007 using the Model Cointegration Error Correction and Engineering, found that the effect of monetary policy on economic growth is much stronger than the effect of fiscal policy. 


\section{Interaction Prediction Pattern Against Monetary-Fiscal Investment}

The effectiveness of fiscal and monetary interaction that most affect investment, both in the short, medium and long is fiscal policy. In the short term, the medium and long interaction of fiscal and monetary to investment more effectively controlled by the fiscal policy through tax revenues.

Fiscal policy is more effective in increasing investment in Indonesia, both in the short, medium and long term. Effectiveness means that the policies on taxes and government spending are more effective in improving the investment compared with the policy on lending rates and money supply. Rising tax revenue will cause a rise in government spending, particularly on capital expenditures that encourage investment. It further illustrates that increasing government spending, the investment is increasing.

The results are consistent with research Eisner (1989) on the American economy in the period 1956 to 1984 to obtain evidence that fiscal policy through government spending positive effect on investment. Chrystal and Thornton (1988) fiscal policy the government budget deficit by increasing government spending is needed to achieve the two macroeconomic objectives, namely full workmanship and high economic growth rates. The pump-priming theory states that the government budget deficit by increasing government spending is needed to rescue the economy from recession. Abhimanyu (2005) argues the government budget deficit is the fiscal stimulus is expansive. Expansionary fiscal policy (increased government expenditure) is needed if the economy is in a lethargic condition, which is characterized by decreased private investment. In this condition, the role of government is essential as an economic stimulator.

\section{Interaction Prediction Pattern against Fiscal-Monetary Exchange}

The effectiveness of fiscal and monetary interaction that most affect the exchange rate, both in the short, medium and long term is fiscal policy. In the short term, the medium and long interaction of fiscal and monetary towards more effective exchange rate is controlled by the fiscal policy through government spending. The conclusion is that fiscal policy is more effective in controlling the exchange rate in Indonesia, both in the short, medium and long term. Effectiveness means that the policies on taxes and government spending are more effective in maintaining the stability of the exchange rate compared to the policy loan interest rates and the money supply. Expansionary fiscal policy will boost production capacity through the increase in investment. Rising production which encourages exports will strengthen the position of the rupiah.

In an open economy, fiscal policy also affects the exchange rate and the trade balance. In the case of fiscal expansion, higher interest rates as a result of government borrowing to attract foreign capital. In their efforts to get more dollars for foreign investment bid up the price of the dollar, causing the appreciation of the exchange rate in the short-term (www. Http://dimalouwrahel.blogspot.com/2011/06/kebijakan-fiskal.html, accessed 2 April 2013).

According to Santoso (2009), fiscal policies through fiscal expansion, for example by increasing government spending and lowering taxes shifts the IS curve to the right and the resulting rise in interest rates will rise. When the interest rate in the country is higher than international interest rates, there will be the capital inflows (capital inflow). This will increase the flow of funds to the domestic request of domestic currency in the foreign exchange market, thus increasing the exchange rate of the domestic currency. This makes the exchange rate appreciation of the domestic currency is more expensive about foreign goods, it reduces net exports. Their fiscal policy regarding the rise in government spending (expansionary fiscal) will drive the IS curve to the right. As a result, domestic interest rates rose and capital inflow from the international community. With a flexible exchange rate policy, the increase in demand for the rupiah will allow the exchange rate changes which cause prices to rise Rupiah (IDR appreciation).

\section{Interaction Prediction Patterns Fiscal-Monetary Against Inflation}

The effectiveness of economic and monetary interaction that most affect inflation, both in the short, medium and long is monetary policy. In the short term, medium and long term fiscal and monetary interaction against inflation more effectively controlled by the monetary policy through interest rate credit control. Monetary policy is more effective in controlling inflation in Indonesia, both in the short, medium and long term. Effectiveness means control policy loan interest rates and the money supply is more effective in maintaining the stability of inflation compared with the policy of tax revenue and government spending. Monetary policy by lowering loan interest rates have an impact on the use of money for the transfer of investment to consumption thus decreasing the money supply which will encourage stable inflation.

These results are consistent research Indrawati (2007) changes in interest rates positively responded by the rate of inflation. The tight monetary policy by raising interest rates also led to a rise in inflation. This indicates a policy of interest rate cuts needed to create a conducive environment for the real sector, while the effect of rising interest rates on the rise in inflation is only temporary responded. Indications expansionary fiscal policies led to an increase in inflation although it takes place quickly and causes a drop in output. 
Abel (2002) used monetary policy to stabilize the economy in the short term while fiscal policy is directed to achieve medium and long-term economy. Meanwhile, monetary policy in the long term can be focused on keeping inflation. Monetary policy is directed at achieving a balance between demand and supply of money. The balance in the money market will affect the balance of market goods. When the money supply more than is required to result in increased demand for goods and services that will increase inflation (Madjid 2007).

Thus the main objective of monetary policy is to regulate the money supply is constantly adjusted to the real needs of the economy. The real needs of the economy in macro-economic planning are the target to be achieved such as economic growth, inflation, and interest rates.

With the Law 23 of 1999 which entered into force on 17 May 1999, the objectives of Bank Indonesia to be just "achieve the goal of a single (single objective), namely inflation. Regarding inflation as a single target, the Bank Indonesia policy in controlling inflation also indirectly controls the exchange rate (exchange rate). Nevertheless, Rupiah exchange rate is not the end goal, but Bank Indonesia to maintain volatility in the exchange rate to achieve the inflation target. Enactment of a single target inflation is motivated by the thought that in the long run monetary policy can only affect the rate of inflation. On the other hand, the low inflation is a prerequisite for the achievement of macroeconomic targets, such as high economic growth and low unemployment. Furthermore, the set inflation target can be a reference for other economic policies.

After analyzing the interaction of monetary and fiscal policy to macroeconomic stability, the writer concludes that monetary policy is more effective than the fiscal policy in maintaining macroeconomic stability in Indonesia, this is because the monetary policy through interest rates and the money supply in the short term and long term able to keep inflation and boost economic growth, where the increase in the money supply (monetary expansion) led to increased demand, resulting in domestic interest rates decline and going capital outflow from the international community so that the lower exchange rate of the domestic currency (exchange rate depreciation), depreciation of the exchange rate this can lead to increased exports that affect the rise in earnings, this is in accordance with the Mundell-Fleming theory that explains the impact of monetary policy on the increase in revenue, as follows:

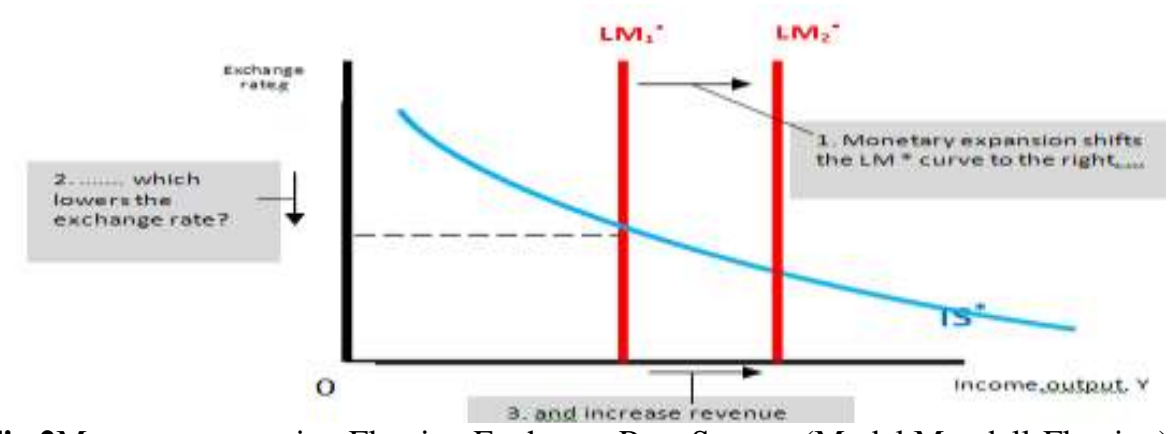

Fig.2Monetary expansion Floating Exchange Rate System (Model Mundell-Fleming)

In the picture above, shows an increase in the money supply (monetary expansion) LM * curve shifts to the right which lowers the exchange rate and increase revenue. The depreciation of the exchange rate makes domestic goods are relatively cheap to foreign goods and boost net exports. The increase in net exports adds to the impact of monetary policy on increasing income (Mankiw, 2007).

While fiscal policy will be less effective in promoting economic growth, this is due to the increase in government expenditure (fiscal expansion) led to increased demand, resulting in domestic interest rates rose and capital inflow from the international community to improve the exchange rate of the domestic currency (exchange rate appreciation), this can lead to exchange rate appreciation of the export decline that led to the decline of income, it is in accordance with the Mundell-Fleming theory explaining the impact of fiscal policy on the reduction in income, as follows:

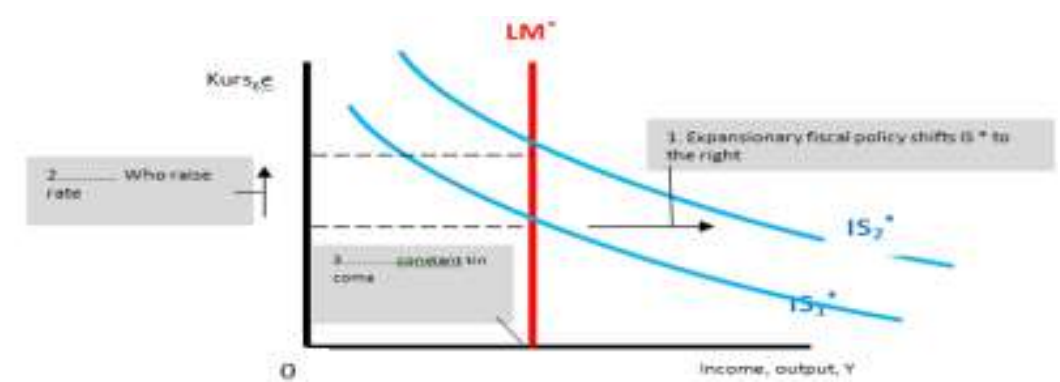

Fig.3Fiscal Expansion Floating Exchange Rate System (Model Mundell-Fleming) 
In the above, showed an increase in government spending (fiscal expansion) causes the IS * curve shifts to the right top, it raised the exchange rate but has no effect on earnings. The appreciation of the exchange rate of the domestic currency makes it relatively expensive to foreign goods, thereby reducing net exports. The decline in net exports reduces the impact of fiscal policy on income.

\section{Conclusions}

The results of the analysis of patterns of prediction of the macro-economic stability in Indonesia showed that the pattern predicted by the policies of fiscal effective in increasing investment and pattern prediction exchange rate stability through tax revenues and government spending. The pattern of predictions for monetary policy is more effective in increasing gross domestic product and pattern predictions for stability control inflation interest rates on credit and the money supply, the monetary policy is more effective to form predictions compared to the pattern predicted by fiscal policy in maintaining macroeconomic stability in Indonesia.

\section{Future Scope}

1. Facing shock output and inflation shocks, the coordination of fiscal and monetary policies have been more helpful than no coordination. Monetary and fiscal policy coordination should be improved through strengthening institutions such as the existence of such Board Fiscal/Monetary. Their fiscal and monetary policy mix accompanied by the institutional investigation (Monetary and Fiscal Coordination Board) is expected to increase macroeconomic stability in Indonesia.

2. The interaction of fiscal and monetary policy in Indonesia has not been effective in the face of shocks to inflation, monetary and fiscal policy coordination in the fight against inflationary pressures from the supply side needs to be improved. Also, it is necessary to coordinate policies in the control of production (especially the availability of staple food such as rice, sugar, soy, chili, onions, meat and so on).

\section{References}

[1] Adiningsih, S. (2012). Koordinasi Kebijakan Fiskal dan Moneter, Tantangan Ke Depan, Kumpulan Paper BI, Jakarta : Kanisius.

[2] Aliman, (2004), Analisis Efektivitas Penerapan Kebijakan Moneter dan Fiskal Dalam Perekonomian Indonesia, Jurnal Ekonomi dan Manajemen, Vol 4 No.1, Januari 2004, Ikatan Sarjana Ekonomi Indoneisa (ISEI).

[3] Ariefianto, M,D. (2012)." Ekonometrika esensi dan aplikasi dengan menggunakan Eviews. Jakarta: Erlangga

[4] Boediono. (2001). Ekonomi Moneter, edisi 3, Yogyakarta : BPFE.

[5] Fleming, J. Marcus (1971), On Exchange Rate Unification,The Economic Journal, Vol 81, hal467-88.

[6] Goeltom, M. S. dan Danny H. (2007). Respon Optimal KebijakanMoneter terhadap Shock Fiskal, pendekatan New Keynesian Open Macroeconomics, Mimeo, Jakarta : Bank Indonesia.

[7] Gujarati, D. N. (2003). Ekonomtrika Dasar. (Edisi Alih Bahasa Terjemahan). Jakarta: Erlangga

[8] Indrawati Y. (2007). Interaksi Kebijakan Fiskal Dan Moneter Di Indonesia : Pendekatan Vector Autoregression. Jakarta : Universitas Indonesia.

[9] Mankiw, N. G. (2007). Teori Makro Ekonomi. Edisi Keenam. Jakarta : Erlangga.

[10] Mankiw, N G.(2006). Principles of Economics, Pengantar Ekonomi Makro. Edisi Ketiga, Alih Bahasa Chriswan Sungkono, Jakarta : Salemba Empat.

[11] Mohanty, M.S. and Michela Scatigna (2010), ountercyclical Fiscal Policy and Central Bank, BIS Working Paper

[12] Manurung, Jonni, J. Manurung, Adler H., Saragih, Ferdinand D. (2009).Ekonometrika. Cetakan Pertama, Jakarta : Elex Media Computindo.

[13] Muhidin, Sambas Ali dan Maman Abdurahman. (2008). Analisis Korelasi, Regresi dan Jalur Dalam Penelitian. Cetakan Pertama, Bandung : CV. Pustaka Setia.

[14] Mundell, R,A (1961). Theory Of Optimum Currency Areas,American Economic Review.379-96.

[15] Nopirin.(2000). Ekonomi Moneter. Buku II. Edisi ke 1, Cetakan Kesepuluh, Yogyakarta: BPFE UGM.

[16] Rusiadi. (2014). Metode PenelitianUntuk Manajemen, Akuntansi dan Ekonomi Pembangunan, Konsep, Kasus dan Aplikasi SPSS, Eviews, Amos dan Lisrel. Cetakan kedua. Medan : USU press. 